DOI 10.18551/rjoas.2021-05.19

\title{
SELF-OPENNESS AND MARRIAGE ADJUSTMENT TO THE QUALITY OF MARRIAGE
}

\author{
Rahmadani Ayunda*, Kardiani Ainun, Indah Maulidya Shalzabila, Suryani Anti \\ Department of Psychology, Mulawarman University, Indonesia
}

\author{
Diana, Salasiah \\ Faculty of Social Science and Political Science, 17 August 1945 University, Indonesia
}

*E-mail: ayunda.ramadhani@fisip.unmul.ac.id

\begin{abstract}
This study aims to determine the influence of self-disclosure and marital adjustment on individuals who have been married for 5-10 years in East Kalimantan Province. This study uses a quantitative approach. This study's subjects were 100 individuals who have been married for 5-10 years in East Kalimantan Province who were selected using the purposive sampling technique. The data collection method used was the scale of self-disclosure, marriage adjustment, and marriage quality. The collected data were analyzed with the Statistical Package for Social Science (SPSS) 21.0 for the windows program. This study indicates that there is a significant influence between self-disclosure and marital adjustment on the quality of marriage with an $F$ value of 109.510 and a $p$ of 0.000 , which has an influence contribution value (R2) of 69,3.
\end{abstract}

\section{KEY WORDS}

Self-openness, marriage adjustment, quality of marriage.

In the process of human development in early adulthood, humans need an intimate relationship with other people in order to get intimacy (Erickson, in Papalia. et al., 2011). One of the relationships that humans can form in early adulthood is a marriage relationship. Uniting two different people in a marriage relationship is not an easy process to go through for a married couple; some couples can have difficulty maintaining their relationship. It is not uncommon for some couples to choose divorce to end their marriage relationship, which is considered quite complicated.

This is per the data on the divorce rate report in Indonesia for the last ten years based on data from the Religious Courts; throughout 2019, there were 480 thousand divorce cases in Indonesia (source: look data.beritagar.id). The increasing number of divorce cases also occurs in East Kalimantan Province. Based on data presented by the Central Bureau of Statistics, each year, there is an increase in East Kalimantan divorce cases. Divorce cases in East Kalimantan Province in 2019 reached 7,803 cases (source: kaltim.bps.go.id).

The increasing number of divorce cases may indicate the poor quality of the marriage relationship for couples who have been married in Indonesia in the last ten years. Meanwhile, the quality of a good marriage is the basis that strengthens the marriage relationship of the couple. The aspects of the quality of marriage, according to Wahyuningsih (2013), are friendship, harmony, and satisfaction with children.

Entering the married life of the couple will go through phases and periods in the marriage relationship. The initial period of marriage usually occurs between 5-10 years of marriage age. According to Hurlock (2012), ten years of marriage is a period of adjustment to one another. Another statement, according to Saidiyah and Julianto (2016), changes in the conditions of marriage often occur after entering the age of five and over. The couple tends to be exposed to conflicts in the relationship, such as parenting, economic problems, and the loss of positive habits that husband and wife usually do.

According to Wood (2013), although conflict is expected in every relationship, conflict cannot be underestimated. When a conflict occurs, the couple must resolve it so that the relationship can be re-established. Efforts that can be made in overcoming conflict include 
trying to communicate openly. According to Indahyani (2013), self-openness is essential for realizing effective interpersonal communication to achieve a more intimate and harmonious relationship. Self-openness is a form of open communication that couples can do to resolve conflicts in their marriage. According to DeVito (2011), the aspects of self-disclosure are quantity, valence, honesty, intention, and intimacy.

Adjustments in the marriage relationship are also the task of every newly married couple. According to Rumondor (2011), the early marriage period is a period full of adjustments in various areas. This is because marriage is a process that unites two persons into one, uniting individuals with their partner's families and the conditions of the environment they will live in.

The adjustment of the individual to his marriage will also reduce conflicts in the marriage relationship itself. If the ability to adjust marriage increases, the marital conflict will decrease, and vice versa (Christina \& Matulessy, 2016). Marriage adjustments that are carried out by individuals properly will improve the relationship's quality in their marriage. The research results evidence this by Muslima \& Herawati (2018); this study found a significant relationship between marriage adjustment and marriage quality. According to Hurlock (2012), the aspects of marriage adjustment are adjustment to a partner, adjustment of a spouse, financial adjustment, and adjustment to the partner's family.

The formulation of the problem and the purpose of this study were to determine the effect of self-disclosure and marital adjustment on the quality of marriage in married couples 5-10 years old in East Kalimantan Province. The hypotheses in this study are:

$\mathrm{H}_{0}$ : There is no influence between self-disclosure and marital adjustment on marriage quality in couples married for 5-10 years in East Kalimantan Province.

$\mathrm{H}_{1}$ : There is an influence between self-disclosure and marital adjustment on marriage quality for couples married for 5-10 years in East Kalimantan Province.

$\mathrm{H}_{0}$ : There is no effect between self-disclosure on marriage quality for couples married for 510 years in East Kalimantan Province.

$\mathrm{H}_{1}$ : There is an influence between self-disclosure on marriage quality for couples married for 5-10 years in East Kalimantan Province.

$\mathrm{H}_{0}$ : There is no effect between marriage adjustments on marriage quality for couples married for 5-10 years in East Kalimantan Province.

$\mathrm{H}_{1}$ : There is an effect between marriage adjustment on marriage quality for couples married for 5-10 years in East Kalimantan Province.

\section{METHODS OF RESEARCH}

This research uses research with a quantitative approach. According to Sugiyono (2017), what is meant by research methods is a scientific way to get data with specific purposes and uses. Quantitative research is also a type of research related to numerical or numerical data so that the data can be analyzed statistically. This study's variables consisted of the dependent variable, namely the quality of marriage, and the independent variables, namely self-disclosure and marital adjustment.

The design used in this research is descriptive and inferential statistics. The descriptive statistical research design was used to provide an overview of the conditions for the distribution of self-disclosure data, marriage adjustments to the quality of marriage in couples who have been married for 5-10 years in East Kalimantan Province. Meanwhile, inferential statistics are used to determine whether there is an effect of self-disclosure or marriage adjustment on marriage quality in individuals who have been married for 5-10 years in East Kalimantan Province.

In this study, the selected population is all individuals who have been married for $5-10$ years in East Kalimantan. From this population, it is necessary to have a generalizable sample to represent the study population (Sugiyono, 2017). This study's sampling technique is non-probability sampling with the sample determination technique, namely purposive sampling. The characteristics of the subjects in this study are subjects domiciled in East Kalimantan Province and are individuals who have been married for 5-10 years. 
According to research by Saidiyah and Julianto (2016), couples who have been in a marital relationship for more than five years will experience many changes in the marriage relationship; they tend to be exposed to more conflicts and problems such as those related to parenting, the economy, and the loss of positive husband-wife habits so that this can provide a predictor picture of the quality of the marriage relationship in the 5-10 years of marriage.

Based on these two characteristics, the number of subjects who meet the criteria is 100 individuals who have been married for 5-10 years in East Kalimantan.

Researchers used data collection tools with three measuring instruments or Likert scale type instruments to obtain accurate data. According to Sugiyono (2017), the Likert scale is used to measure an individual's perceptions, opinions, and attitudes regarding social phenomena. In this study, the instruments used were compiled to measure three related variables: the scale of marriage quality, self-disclosure, and marital adjustment.

After scale compiled was tested, then processed using the Statistical Package for Social Science (SPSS) 21.0 for Windows. From the results of data processing, the level of validity and reliability of each scale can be seen. Then proceed with data analysis using multiple regression analysis to determine how much influence and predictive ability of the two independent variables (self-disclosure and marital adjustment) on the dependent variable (quality of marriage).

\section{RESULTS OF STUDY}

The validity test results of the data distribution of the three scales, namely the marriage quality scale, showed 25 items declared valid and one item declared invalid or invalid, the self-disclosure scale showed 39 items declared valid, and one item declared invalid or invalid. Invalid, and the marital adjustment scale shows that none of the items fail and is declared valid.

Furthermore, the results of the reliability test of the data distribution of the three scales, namely the scale of the quality of marriage, showed an alpha value of $>0.600$, with an alpha value for the quality of marriage variable $=0.890$, the self-disclosure scale showing an alpha value $>0.600$, with an alpha value for the self-disclosure variable $=0.947$ and the adjustment scale. Marriage shows an alpha value $>0.600$, with the alpha value for the marital adjustment variable $=0.935$. The three variables are stated to be very reliable or very reliable.

Individuals who are the subject of this study have been married for 5-10 years who reside in East Kalimantan Province. The characteristics of research subjects can be seen in the following table:

Table 1 - Subject Characteristics by Age

\begin{tabular}{llll}
\hline No & Age & Total & Percentage \\
\hline 1. & $24-27$ years & 30 & $30 \%$ \\
2. & $28-31$ years & 28 & $28 \%$ \\
3. & $32-35$ years & 20 & $20 \%$ \\
4. & $36-40$ years & 22 & $22 \%$ \\
\hline & Total & 100 & $100 \%$ \\
\hline
\end{tabular}

Based on table 1 above, it can be seen that the members of the research subject aged 24-27 years are 30 members (30 percent), 28-31 years old totaling 28 members (28 percent), aged $32-35$ years numbered 20 members (20 percent) and ages 36-40 years amounted to 22 members (22 percent). So it can be concluded that the research subjects who are individuals married for 5-10 years of marriage in East Kalimantan Province are dominated by members aged 24-27 years, amounting to 30 members or 30 percent.

From table 2 it can be seen that the members of the research subject who are male are a total of 35 members ( 35 percent), and those who are female are 65 members (65 percent). So it can be concluded that the research subjects in individuals married for 5-10 years in East Kalimantan Province are dominated by female members, namely 65 members or 65 percent. 
Table 2 - Characteristics of Subjects Based on Gender

\begin{tabular}{llll}
\hline No & Gender & Total & Percentage \\
\hline 1. & Male & 35 & $35 \%$ \\
2. & Female & 65 & $65 \%$ \\
\hline & Total & 100 & $100 \%$ \\
\hline
\end{tabular}

Table 3 - Characteristics of Subjects Based on Domicile

\begin{tabular}{llll}
\hline No & Domicile & Total & Percentage \\
\hline 1. & Balikpapan & 42 & $42 \%$ \\
2. & Bontang & 10 & $10 \%$ \\
3. & Kutim & 2 & $2 \%$ \\
4. & Muara Badak & 4 & $4 \%$ \\
5. & Paser & 2 & $2 \%$ \\
6. & PPU & 3 & $3 \%$ \\
7. & Samarinda & 28 & $28 \%$ \\
8. & Samboja & 2 & $2 \%$ \\
9. & Tenggarong & 7 & $7 \%$ \\
\hline
\end{tabular}

Based on table 3 above, it can be seen that the members of the research subject who come from the domicile of Balikpapan are 42 members (42 percent), the domicile of Bontang is ten members. (10 percent), the domicile of Kutim is two members (2 percent), the domicile of Muara Badak is four members (4 percent), the domicile of Paser is two members (2 percent), the domicile of the PPU is three members (3 percent), the domicile of Samarinda is 28 members (28 percent), the domicile of Samboja is two members (2 percent). The domicile of Tenggaring is seven members (7 percent). It can be concluded that the research subjects in individuals or 5-10 married couples in East Kalimantan Province are dominated by members domiciled in Balikpapan, amounting to 42 members or 42 percent.

This study's hypothesis is to determine the effect of self-disclosure and marital adjustment on the quality of marriage in married couples 5-10 years in East Kalimantan Province. Based on the results of the full regression model test on the variables of selfdisclosure and marital adjustment to the quality of marriage together, the following results were obtained:

Table 4 - Hypothesis Test Results of Regression Analysis of full Model

\begin{tabular}{|c|c|c|c|c|}
\hline Variable & F count & F table & $\mathrm{R}^{2}$ & $P$ \\
\hline $\begin{array}{l}\text { Quality of Marriage }(\mathrm{Y}) \\
\text { Self-disclosure }(\mathrm{X} 1) \\
\text { Marriage Adjustment (X2) }\end{array}$ & 109.510 & 3.09 & 0.693 & 0.000 \\
\hline
\end{tabular}

Table 5 - Hypothesis Test Results of Regression Analysis of the Model

\begin{tabular}{llrr}
\hline Variable & Beta & T count & T table \\
\hline Self-Openness (X1) & & & \\
Quality of Marriage (Y) & 0.100 & 1.015 & 1.984 \\
Marriage Adjustment (X2) & 0.748 & 7,577 & 1,984 \\
Quality of Marriage (Y) & & 0.000 \\
\hline
\end{tabular}

Based on table 4 above, the results show that $F$ count $>F$ table, which means that selfdisclosure and marital adjustment on the quality of marriage has a very significant effect with the value of $F=109.510, R 2=0.693$, and $p=0.000$. This means that the significant hypothesis in this study is accepted.

Based on table 5 above, on self-disclosure towards the quality of marriage, it can be seen that $t$ count $<\mathrm{t}$ table, which means that there is no significant effect between selfdisclosure on the quality of marriage with a beta value $=0.100$, $t$ count $=1.015$, and $p=$ 0.313 ( $p>0.05)$.

The adjustment of marriage to the quality of marriage shows $t$ count $>t$ table, which means that there is a significant influence between marriage adjustment on the quality of marriage with a beta value $=0.748$, $t$ count $=7.577$, and $p=0.000(p<0.05)$. 


\section{DISCUSSION OF RESULTS}

This study aims to determine the effect of self-disclosure and marital adjustment on marriage quality for 5-10 years married couples in East Kalimantan Province. The results of the full regression model analysis hypothesis test show that the significant hypothesis in this study is accepted, which means that self-disclosure and marital adjustment to the quality of marriage have a significant effect.

The contribution of the influence (R2) of self-disclosure and marital adjustment to the quality of marriage is 0.693 ; this shows that 69.3 percent of the variation in marriage quality can be explained by self-openness and marital adjustment. Simultaneously, the remaining 30.7 percent is explained by other variables or other causes not examined in this study.

This can also be in line with previous research by Sakinah and Kinanth (2018), which states that self-disclosure has a role in marriage satisfaction, which indirectly evaluates the quality of the couple's marital relationship. Furthermore, the results of previous research conducted by Rahmah et al. (2018) revealed that marriage adjustment is one of the predictor factors in the quality of the marital relationship of married couples.

Couples who are married for 5-10 years of marriage are considered to be in the initial period of the marriage relationship so that it is possible for couples who are in the 5-10 year period of marriage to feel tension and feelings of love that are still very passionate between one another.

Barash's (2012) statement that the initial period is a beautiful period for married couples because husband and wife are still filled with feelings of love and passion. Moreover, another opinion states that ten years of marriage could be difficult to go through because of the many emotional tensions that occur in young families (Walgito, 2000).

In the marriage relationship, the couple is also faced with conflicts and problems in the family that can influence the couple in evaluating their happiness and satisfaction in the marriage relationship. Previous research by Saidiyah and Julianto (2016) revealed problems that have arisen in the ten years of marriage, namely, economic problems, loss of positive husband-wife habits due to lack of open communication, and differences of opinion in childcare.

Problems related to the lack of open communication and differences of opinion arise due to the lack of self-disclosure between married couples. Conditions that are not open to one another can lead to differences in perceptions and conflict. Self-openness is considered to be a way that can be used to solve problems and difficulties in communication problems and adjustments to one another so that partners can ask each other what they want and understand each other what their partners want or think as a form of reducing ongoing conflicts (Devito, 2011).

Another problem that can arise in a marriage relationship in the early period is related to couples and individuals' adjustment in family life. This is in line with the statement of Hurlock (2012), which states that in the first and second years of marriage, married couples must adjust to their partners, with the spouse's family and with friends owned by the partner. This situation is considered to cause emotional tension. This can be one of the triggers for decreased happiness and satisfaction with the marriage relationship, so that it can affect the quality of the marriage.

Therefore, the factors that influence the quality of marriage include self-disclosure, which is stated indirectly to have a role in the quality of marriage based on the research results by Sari et al. (2018), showing that self-disclosure has a significant positive relationship to the quality of marriage. And other factors, namely marriage adjustments. The higher the marriage relationship's adjustment, the higher the satisfaction in the marriage relationship and the quality of marriage in married couples (Rahmah et al., 2016).

Furthermore, based on the regression analysis of the gradual model hypothesis test, self-disclosure towards the quality of married couples for 5-10 years in East Kalimantan Province shows no significant effect. This means that self-disclosure does not significantly influence the quality of marriage for couples married for 5-10 years. 
The results of this study are not per previous research by Sakinah and Kinanth (2018), which shows that self-disclosure has a role in the condition of marriage satisfaction which is an evolution of the quality of the marriage relationship by 8.7 percent while 91.3 percent is influenced by other factors not described in the study.

Another factor that can affect the quality of marriage is interpersonal communication. According to Devito (2011), communication can help deal with conflicts in a relationship, including marital relationships. One form of communication that is also expressed as a solution in problem-solving is interpersonal communication. This is by previous research that revealed that interpersonal communication has a role in marriage quality (Paramita \& Suarya, 2018).

Furthermore, based on the results of the stepwise regression model analysis hypothesis test, marriage adjustment on the quality of marriage for couples married for 5-10 years in East Kalimantan Province shows that there is a significant effect, which means that the higher the marriage adjustment, the higher the quality of marriage in married couples and vice versa. The lower the marital adjustment, the lower the quality of marriage in married couples.

This is in line with previous research on predictors of marriage quality by Rahmah., Et al. (2018), which revealed that marriage adjustment is one predictor of the quality of marriage. In this study, the resulting aspect of marriage adjustment, which has the highest predictive ability for marriage quality, is the marriage satisfaction felt by both husband and wife so that it can be concluded that the importance of marriage adjustment factors in order to obtain marriage satisfaction and improve the quality of the couple's marriage.

Other studies that reveal the same thing regarding differences in marital satisfaction in terms of marital adjustment ability of TNI-AL wives who undergo Long Distance Marriage show that wives who make higher marital adjustments have higher marital satisfaction than wives with more marital adjustment rates Low. This means that the higher the level of marriage adjustment, the higher the sense of satisfaction in the marriage relationship, affecting the quality of the couple's marriage (Rachmawati \& Mastuti, 2013).

In research conducted by researchers, it can be seen that the characteristics of research respondents based on age are dominated by members of the 24-27 year age group with 30 members or 30 percent, which indicates that the respondents in this study are on average in early adulthood.

Besides, it can also be seen that female members dominate research respondents' characteristics based on gender. There are 65 female members or 65 percent of them. So it can be concluded that the group of respondents in this study, on average, were women who were in early adulthood. This then can support the statement, which states that the level of adjustment of women's role in early adulthood to marriage is considered relatively high (Hurlock, 2012).

\section{CONCLUSION}

Based on the study results, it is concluded that self-disclosure and marital adjustment have a significant effect on the quality of marriage. Then marriage adjustment has a significant positive effect on the quality of marriage, while self-disclosure does not affect marriage quality. This can occur because other factors affect the quality of marriage, one of which is interpersonal communication. When a married couple involves interpersonal communication skills, including open communication, empathy, positive attitudes, effective communication, and a sense of equality, individuals and partners can understand each other's desires and viewpoints and resolve problems/conflicts.

Couples who can reduce conflict and solve problems well can maintain a harmonious marriage relationship in it. When this harmony is formed and getting better, the married couple can also improve their marriage relationship quality.

The researcher's suggestion for the research subject is that the subject is expected to maintain the marital relationship by making adjustments in the marriage relationship - both 
adjustments to spouses, partner's family, household economic conditions, and sexual needs of partners.

Suggestions for married couples are to be more open and establish close interpersonal communication with their partners; this can be done so that married couples can more honestly express each other to understand each other's desires.

Suggestions for further researchers who are interested in researching the quality of marriage should examine more broadly the factors that can affect the quality of marriage considering that in the results of this study, there are variables that do not influence the quality of marriage, namely self-disclosure so that further researchers are expected to find findings that better than the research that has been done.

\section{REFERENCES}

1. Badan Pengadilan Agama. (2019). Kasus gugat cerai talak Indonesia. https://lokadata.beritagar.id/chart/preview/kasus-cerai-gugat-dan-talak-di-indonesia-20142019-1582104258 diakses pada 26 Maret 2020.

2. Badan Pusat Statistik Kalimantan Timur. (2019). Jumlah nikah cerai Kalimantan Timur. https://kaltim.bps.go.id/dynamictable/2019/11/07/449/jumlah-nikah-dan-cerai-menurutkabupaten-kota-di-Provinsi-kalimantan-timur-2019.html diakses pada 26 Maret 2020.

3. Barash, S.S. (2012). The Nine phases of marriage: how to make it, break it, keep it. New York: St. Martin's Griffin.

4. Christina, D., \& Matulessy, A. (2016). Penyesuaian perkawinan, subjective-well being and konflik perkawinan. Persona: Jurnal Psikologi Indonesia, 5(01), 1-14.

5. Devito, J. A. (2011). Komunikasi antar manusia. (Ed.5).Tangerang: Karisma Publishing Group.

6. Hurlock, E. B. (2012). Psikologi perkembangan (Ed.5). Jakarta: Erlangga.

7. Indahyani, I. (2013). Memahami komunikasi antar pribadi dalam pernikahan beda agama dalam upaya mempertahankan hubungan yang harmonis. Jurnal The Messenger, 5(2), 47-54.

8. Muslima, F., \& Herawati, T. (2018). The role of social support and marital adjustment to marital quality of married student. Journal of Family Sciences, 3(2), 30-41.

9. Papalia, D.E., Olds, S. W., \& Feldman, R. D. (2011). Human Development (Ed.9). Jakarta: Kencana: McGraw Hill Companies.

10. Rachmawati, D., \& Mastuti, E. (2013). Perbedaan tingkat kepuasan perkawinan ditinjau dari tingkat penyesuaian perkawinan pada istri brigif 1 marinir TNI-AL yang menjalani long distance marriage. Jurnal Psikologi Pendidikan and Perkembangan, 2(01), 1-8.

11. Rahmah, A. A., Rahman, A. A., \& Fitriah, E. A. (2018). Prediktor kualitas pernikahan: Penyesuaian pernikahan and nilai personal. Jurnal Psikologi.

12. Rumondor, P. C. (2011). Gambaran penyesuaian diadik pada pasangan dewasa muda di awal pernikahan. Humaniora, 2(1), 468-476.

13. Saidiyah, S., \& Julianto, V. (2016). Problem pernikahan and strategi penyelesaiannya: Studi kasus pada pasangan suami istri dengan usia perkawinan di bawah sepuluh tahun. Jurnal Psikologi Undip, 15(2), 124-133.

14. Sakinah, F., \& Kinanth, M. R. (2018). Pengungkapan diri and kepuasan pernikahan pada individu yang menikah melalui proses ta'aruf. Jurnal Psikologi Integratif, 6(1), 29-49.

15. Sugiyono. (2017). Metode penelitian kuantitatif kualitatif and R\&D. Bandung: Alfabeta.

16. Wahyuningsih, H. dkk. (2013). The Indonesian moslem marital quality scale: development, validation, and reliability. The Asian Conference on Psychology \& the Behavioral Sciences. Publisher at Osaka, Japan.

17. Walgito, B. (2000). Bimbingan and konseling perkawinan. (ed-2). Yogyakarta: Penerbit ANDI.

18. Winarsunu, T. (2010). Statistik dalam penelitian psikologi and pendidikan. Malang: UMM Press.

19. Wood, J. T. (2013). Komunikasi interpersonal interaksi keseharian. Jakarta: Salemba Humanika. 